\title{
Prediction of microRNAs affecting mRNA expression during retinal development
}

\author{
Amit Arora ${ }^{\dagger}$, Jasenka Guduric-Fuchs ${ }^{\dagger}$, Laura Harwood, Margaret Dellett, Tiziana Cogliati, David A Simpson ${ }^{*}$
}

\begin{abstract}
Background: MicroRNAs (miRNAs) are small RNA molecules ( 22 nucleotides) which have been shown to play an important role both in development and in maintenance of adult tissue. Conditional inactivation of miRNAs in the eye causes loss of visual function and progressive retinal degeneration. In addition to inhibiting translation, miRNAs can mediate degradation of targeted mRNAs. We have previously shown that candidate miRNAs affecting transcript levels in a tissue can be deduced from mRNA microarray expression profiles. The purpose of this study was to predict miRNAs which affect mRNA levels in developing and adult retinal tissue and to confirm their expression.

Results: Microarray expression data from ciliary epithelial retinal stem cells (CE-RSCS), developing and adult mouse retina were generated or downloaded from public repositories. Analysis of gene expression profiles detected the effects of multiple miRNAs in CE-RSCs and retina. The expression of 20 selected miRNAs was confirmed by RT-PCR and the cellular distribution of representative candidates analyzed by in situ hybridization. The expression levels of miRNAs correlated with the significance of their predicted effects upon mRNA expression. Highly expressed miRNAs included miR-124, miR-125a, miR-125b, miR-204 and miR-9. Over-expression of three miRNAs with significant predicted effects upon global mRNA levels resulted in a decrease in mRNA expression of five out of six individual predicted target genes assayed.

Conclusions: This study has detected the effect of miRNAs upon mRNA expression in immature and adult retinal tissue and cells. The validity of these observations is supported by the experimental confirmation of candidate miRNA expression and the regulation of predicted target genes following miRNA over-expression. Identified miRNAs are likely to be important in retinal development and function. Misregulation of these miRNAs might contribute to retinal degeneration and disease. Conversely, manipulation of their expression could potentially be used as a therapeutic tool in the future.
\end{abstract}

\section{Background}

miRNAs are small RNA molecules of 18-22 nucleotides in length which regulate gene expression. Precursor RNAs transcribed either as independent genes or within introns of coding genes are processed by the RNAseIII enzymes Drosha and Dicer to form the mature miRNAs [1]. The first miRNAs were discovered as a result of their role in the timing of adult cell fate determination in Caenorhabditis elegans. Both let-7 and lin-4 are temporally regulated and cause a decrease in expression of

\footnotetext{
* Correspondence: david.simpson@qub.ac.uk

+ Contributed equally

Centre for Vision and Vascular Science, Queen's University Belfast, Ophthalmic Research Centre, Institute of Clinical Science, Royal Victoria Hospital, Belfast BT12 6BA, UK
}

(c) 2010 Arora et al; licensee BioMed Central Ltd. This is an Open Access article distributed under the terms of the Creative Commons Attribution License (http://creativecommons.org/licenses/by/2.0), which permits unrestricted use, distribution, and reproduction in any medium, provided the original work is properly cited.

target proteins which control developmental stage-specific events [2-4]. The significance of miRNAs in developmental processes has now been shown in many plants and animals [5].

There is growing evidence that miRNAs play an important role in regulating eye development and function. In the mouse, prevention of miRNA maturation by conditional knockout in retinal tissue of the Dicer protein resulted in formation of photoreceptor rosettes and retinal degeneration and had a profound effect upon visual function, as measured by electroretinogram (ERG) [6]. Li and Carthew reported reciprocal negative regulation between Yan protein and miR-7 in Drosophila retinal cells: Yan directly represses the expression of miR-7 in undifferentiated progenitor cells and miR-7 directly 
represses the expression of Yan in differentiated photoreceptor cells [7]. The switch between these mutually exclusive expression states occurs when Yan degradation is triggered by epidermal growth factor receptor (EGFR) signaling.

Expression of various miRNAs has been demonstrated in the retina [8-10], notably a sensory organ-specific polycistronic cluster comprising miR-96, miR-182, and miR-183 [11]. The profile of miRNAs expressed in the retina has been shown to change during degeneration in several mouse models $[12,13]$. Many genes with retinalspecific functions are predicted to be targeted by miRNAs and functional interactions have been demonstrated [14].

miRNAs were initially thought to act through inhibition of protein translation [2]. Whilst this mechanism has been widely confirmed [15] and the global impact of miRNAs on protein levels demonstrated $[16,17]$, it has become apparent that miRNAs also affect mRNA levels. This was first clearly demonstrated by the observation that those mRNAs with reduced expression following over-expression of a specific miRNA were enriched for predicted target sites of that miRNA [18]. Many miRNAs display tissue-specific expression [19] and inhibit expression of genes which are found at lower levels relative to other tissues $[18,20]$. The action of miRNAs upon mRNA levels has been widely confirmed in subsequent studies [21,22], which have also improved understanding of the properties of functional predicted target sites $[16,23]$.

Inhibition of gene expression by miRNAs is mediated by base pairing between the miRNA and complementary sequences in the 3'UTR of target genes. However, unlike siRNAs, which direct cleavage of perfectly matched sequences, miRNAs have imperfect complementarity with their target sites. The features required for a functional target site are not fully understood, but include a stretch of perfect complementarity with a $\sim 7$ nucleotide 'seed' region at the 5' end of the miRNA [24]. A range of target prediction algorithms have been developed and each miRNA is thought to target approximately 200 transcripts $[25,26]$. Over 550 human miRNAs have been defined to date (miRBase v12 $[27,28]$ ) and have been suggested to regulate $30 \%$ of genes [24].

We have shown recently that the effects of miRNAs upon mRNA levels are such that the consequences of expression of a specific miRNA can be detected within a single gene expression profile [29]. Here this approach is applied to three experimental samples chosen to indicate candidate miRNAs affecting mRNA levels in ciliary epithelium-derived retinal stem cells from the adult eye (CE-RSCs), the developing retina during rod photoreceptor differentiation (postnatal murine retina) and in the mature retina (adult murine retina). This analysis may be indicative of those miRNAs with greatest effects upon target gene expression, or may reveal a subset with targets which are more susceptible to mRNA degradation. In either case, demonstration of the expression of these miRNAs confirms them as candidates for future manipulation aimed at directing differentiation or maintaining the mature retina.

\section{Results}

In silico prediction of candidate miRNAs affecting mRNA levels

Each miRNA was mapped to its predicted target genes in each mRNA expression profile and the average levels of the transcripts of their target genes were calculated. The ranked average target gene expression values in the $\mathrm{P} 4$ retina are shown in Figure 1A. The probability that each miRNA has a significant effect upon gene expression was calculated using the Wilcoxon ranked sum test; the results for P4 retina are illustrated in Figure 1B. The predictions from all gene expression datasets are listed in Additional file 1: Table S1 and the significant combined probabilities are shown in Table $1(\mathrm{p}<0.05)$. Multiple mRNA expression profiles were analysed for murine CE-RSCs, P4 and adult retina. Significant predicted effects upon mRNA expression were detected for multiple miRNAs in the $\mathrm{P} 4$ and adult retina and for a smaller number in CE-RSCs. At P4 many miRNAs had highly significant effects, with miR-124, miR-125 and miR-9 being particularly significant (Figure 1, Table 1 and Additional file 1: Table S1). In the adult retina miR124 and miR-125 were again prominent, but others, including miR-24, miR-326, miR-370, miR-96 and let-7 also had highly significant predicted effects. The greater number of genes assayed for the adult retina may have contributed to the detection of several more miRNAs with significant predicted effects and the smaller pvalues than at $\mathrm{P} 4$. Whilst most of the candidate miRNAs predicted to affect mRNA levels $(\mathrm{P}<0.05)$ at $\mathrm{P} 4$ were also in the adult, only miR-125, miR-378 and miR-24 were detected in all the different tissue types and developmental stages. Gene expression data from human CERSCs from adult eyes were also analysed and although many different miRNAs were predicted to be affecting mRNA levels, it was notable that the two miRNAs with the most significant effects in murine CE-RSCs, miR378 and miR-485-3p, were also the $3^{\text {rd }}$ and $4^{\text {th }}$ most significant in human CE-RSCs (Additional file 1: Table S1). We hypothesized that miRNAs with detectable effects upon mRNA expression are more highly expressed than those with no effect. We tested this hypothesis in the adult mouse retina using miRNA expression data published by Loscher et al. [13]. A list was compiled of miRNAs whose predicted target genes exhibited significantly low expression. Expression of miRNAs within this 
Table 1 miRNAs predicted to affect retinal gene expression.

\begin{tabular}{|c|c|c|c|c|c|}
\hline CE-RSCs & & P4 & & Adult & \\
\hline miRNA & Probability & miRNA & Probability & miRNA & Probability \\
\hline $\begin{array}{l}\text { miR-485- } \\
3 p\end{array}$ & $2.25 \mathrm{E}-03$ & miR-124a & $5.59 \mathrm{E}-11$ & miR-125 & $8.01 \mathrm{E}-18$ \\
\hline miR-378 & $1.08 \mathrm{E}-02$ & miR-9 & $2.29 \mathrm{E}-10$ & miR-124a & $2.86 \mathrm{E}-15$ \\
\hline $\begin{array}{l}\mathrm{miR}-30- \\
3 p\end{array}$ & $1.14 \mathrm{E}-02$ & miR-125 & 3.92E-09 & let-7 & 8.96E-09 \\
\hline miR-125 & 1.30E-02 & miR-15 & $1.44 \mathrm{E}-07$ & miR-24 & $6.94 \mathrm{E}-08$ \\
\hline miR-153 & $2.14 \mathrm{E}-02$ & $\begin{array}{l}\text { miR- } \\
124 u\end{array}$ & $8.98 \mathrm{E}-05$ & miR-96 & $6.61 \mathrm{E}-07$ \\
\hline miR-342 & 2.46E-02 & miR-34 & $3.36 \mathrm{E}-04$ & miR-370 & $9.17 \mathrm{E}-07$ \\
\hline $\begin{array}{l}\text { miR-142- } \\
5 p\end{array}$ & $2.59 \mathrm{E}-02$ & miR-204 & 3.37E-04 & miR-326 & $1.68 \mathrm{E}-06$ \\
\hline let-7 & 2.69E-02 & miR-378 & $3.55 \mathrm{E}-04$ & miR-29 & 7.82E-06 \\
\hline miR-24 & 2.99E-02 & miR-20 & $5.95 \mathrm{E}-04$ & miR-331 & $9.74 \mathrm{E}-06$ \\
\hline miR-183 & $3.00 \mathrm{E}-02$ & miR-96 & $6.40 \mathrm{E}-04$ & $\begin{array}{l}\text { miR- } \\
124 \mathrm{u}\end{array}$ & $5.14 \mathrm{E}-05$ \\
\hline miR-370 & 4.42E-02 & miR-25 & $1.05 \mathrm{E}-03$ & miR-20 & 8.02E-05 \\
\hline \multirow[t]{14}{*}{ miR-33 } & 4.43E-02 & miR-27 & $1.65 \mathrm{E}-03$ & miR-27 & $5.56 \mathrm{E}-04$ \\
\hline & & let-7 & $2.20 \mathrm{E}-03$ & miR-196 & $1.32 \mathrm{E}-03$ \\
\hline & & miR-326 & 2.79E-03 & $\begin{array}{l}\text { miR-485- } \\
5 p\end{array}$ & $2.87 E-03$ \\
\hline & & miR-150 & 8.95E-03 & miR-34 & 3.35E-03 \\
\hline & & miR-196 & 1.26E-02 & miR-378 & 4.73E-03 \\
\hline & & miR-184 & 1.33E-02 & miR-127 & $5.00 \mathrm{E}-03$ \\
\hline & & miR-448 & $1.56 \mathrm{E}-02$ & miR-30 & $6.74 \mathrm{E}-03$ \\
\hline & & miR-503 & 2.76E-02 & miR-150 & $1.21 \mathrm{E}-02$ \\
\hline & & $\begin{array}{l}\text { miR-485- } \\
5 p\end{array}$ & $3.33 \mathrm{E}-02$ & miR-128 & $1.32 \mathrm{E}-02$ \\
\hline & & miR-30 & 3.44E-02 & miR-15 & 2.30E-02 \\
\hline & & miR-24 & $3.98 \mathrm{E}-02$ & miR-9 & 2.62E-02 \\
\hline & & miR-29 & $4.29 \mathrm{E}-02$ & miR-214 & $2.69 \mathrm{E}-02$ \\
\hline & & & & miR-204 & $2.93 \mathrm{E}-02$ \\
\hline & & & & miR-184 & 4.05E-02 \\
\hline
\end{tabular}

The miRNAs with significant effects (combined $p<0.05$ ) upon mRNA expression in mouse adult CE-RSCs, P4 and adult retina.

group was significantly higher than that of those miRNAs for which no effect on target mRNAs was predicted (Figure 2).

\section{Experimental analysis of miRNA expression}

The following miRNAs had highly significant predicted effects on target mRNA levels and were selected for analysis by RT-PCR: miR-124, miR-125, miR-9, and miR-24. A range of other candidates with p-values < 0.05 in at least one experimental condition (miR-128, miR-150, miR-204, miR-25, miR-27, miR-326 miR-34, miR-370, miR-378 and miR-485-5p) were selected to represent different predicted patterns of activity or for their lack of previous association with neural tissue. In addition, miR-122, which had $\mathrm{p}<0.1$ in CE-RSCs and $\mathrm{P} 4$ and adult retina, was of interest because it has been previously characterised as a highly expressed, liver-specific miRNA $[19,22,30]$; the possibility of an alternative role in the retina is intriguing. Let7d has previously been shown to be highly expressed in the retina [14] and was used as a positive control.

The pattern of relative expression in the three samples considered (porcine CE-RSCs, mouse P4 and adult retina) varied widely amongst miRNAs (Figure $3 \mathrm{~A}$ ). The expression of each individual miRNA corresponded broadly with its predicted effects upon target gene expression (e.g. miR25 highest at $\mathrm{P} 4$ and miR-124 absent in CE-RSCs but present in $\mathrm{P} 4$ and adult mouse retina). However, whilst this analysis indicates the sample in which the relative expression of a single miRNA is highest, it gives no indication of the inter-miRNA variation in expression in that sample. It is also important to consider the relative absolute expression of different miRNAs within a single sample when considering the impact of each upon target mRNA expression. Therefore, starting template copy numbers were estimated for each miRNA based on threshold cycle $(\mathrm{Ct})$ and amplification efficiency or by the linear regression efficiency method [31], which were broadly in agreement (Additional file 2: Figure S1). The miRNAs measured in each sample are shown in Figure 3B ranked by their starting template copy number in the RT-PCR assays. Those miRNAs with the most significant predicted effects upon mRNA expression are highly expressed. Notably, miR-125 has amongst the most significant predicted effects upon mRNA expression at all stages (Table 1) and miR-125a and miR-125b are the most highly expressed miRNAs in all samples (Figure 3B). Furthermore, miR-124 is highly expressed in $\mathrm{P} 4$ and adult retina in accordance with its predicted effects. To test the expected relationship between predicted effects and miRNA expression, the estimated miRNA copy numbers were plotted against predicted probability (Figure 4). This revealed a significant correlation (Spearman rank correlation, $\mathrm{p}=4.0 \mathrm{E}-04$ ), with the majority of most highly expressed miRNAs having highly significant predicted effects.

In situ hybridization (ISH) was performed to localise expression of selected miRNAs (Figure 5). Expression in the adult murine retina of the well-characterised neural miRNA miR-124 concurred with published reports [9]. In P4 retina, miR-124 positive signal was mainly colocalised with ganglion and amacrine cells. Expression of miR-34a, which has not previously been described in the retina, was detected in the porcine CE-RSC neurospheres and throughout the mouse $\mathrm{P} 4$ retina. In the adult mouse retina the strongest signal was observed in the inner nuclear layer (INL) and in some cells in the ganglion cell layer (GCL). miR-128 was expressed in all samples, notably in CE-RSC neurospheres and the inner plexiform layer of the retina at P4. miR-125b was also expressed at all stages with strong signal in the inner plexiform layer at P4. In 

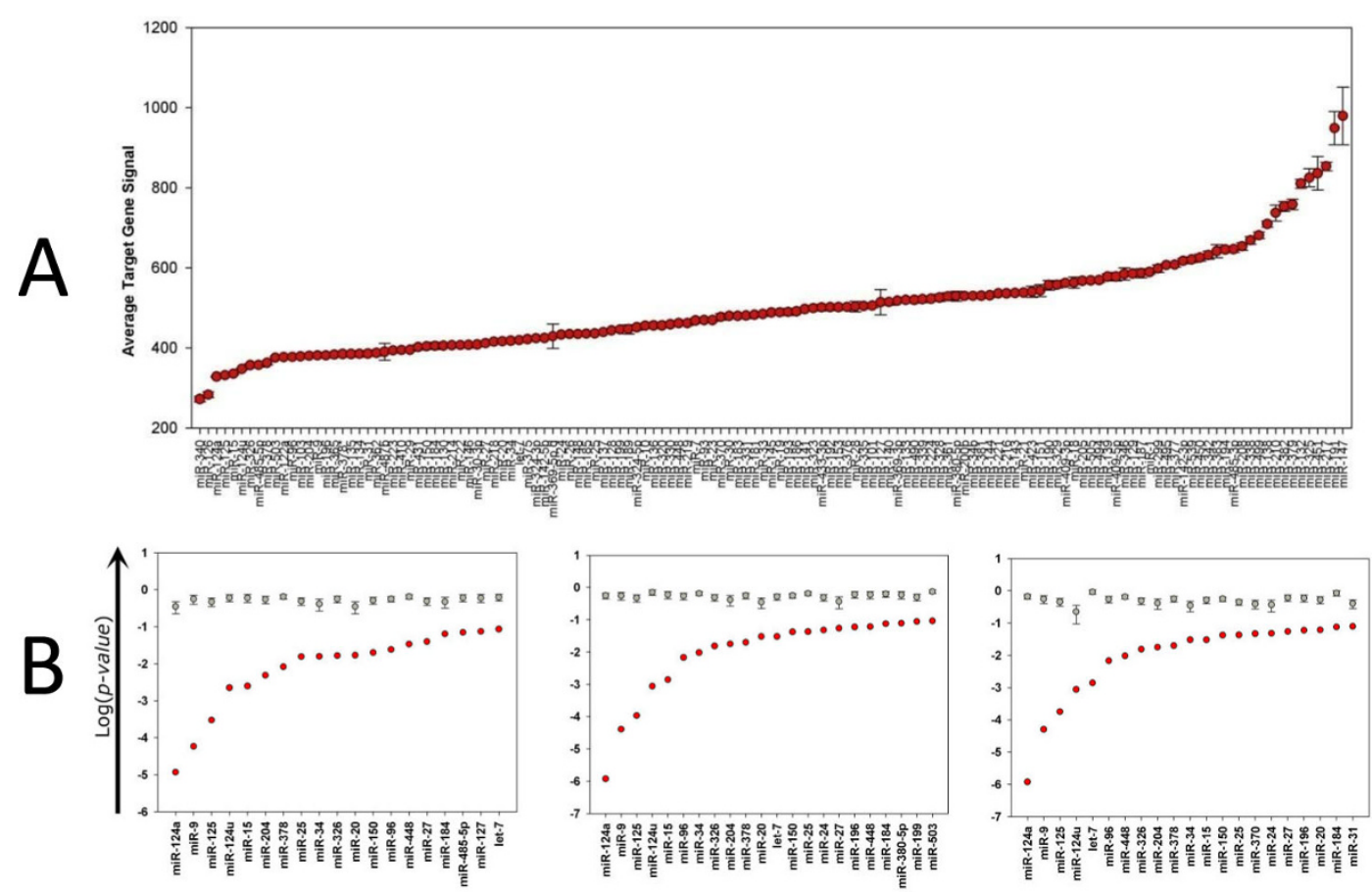

Figure 1 miRNA target gene expression. (A) miRNAs ranked by target gene expression levels (Average Target Gene Signal) in P4 retina. (B) Probabilities of each miRNA having a significant effect $(p<0.1)$ upon target gene expression according to Wilcoxon ranked sum test. The log 10 ( $p$-value) for each miRNA ( $x$-axis) is plotted as a red circle and the mean probability ( \pm standard error) derived from five random sets of predicted target genes is plotted in grey.

the adult retina miR-125b was expressed in the inner and outer nuclear layers. No expression was observed for miR122 and miR-378 (data not shown).

\section{Predicted targets of candidate miRNAs affecting mRNA} levels

In order to identify the genes most likely regulated by miRNAs in CE-RSCs, P4 and adult retina, the target predictions for all the miRNAs shown to have a significant effect upon gene expression were combined. This revealed that some genes were predicted to be targeted by almost half of the miRNAs identified in each sample (Table 2 and Additional file 3: Table S2). These genes are the most likely to be real miRNA targets because if some predicted sites are not functional others may be active. Also, the co-operative action of multiple miRNAs may result in greater effects [23]. Six genes
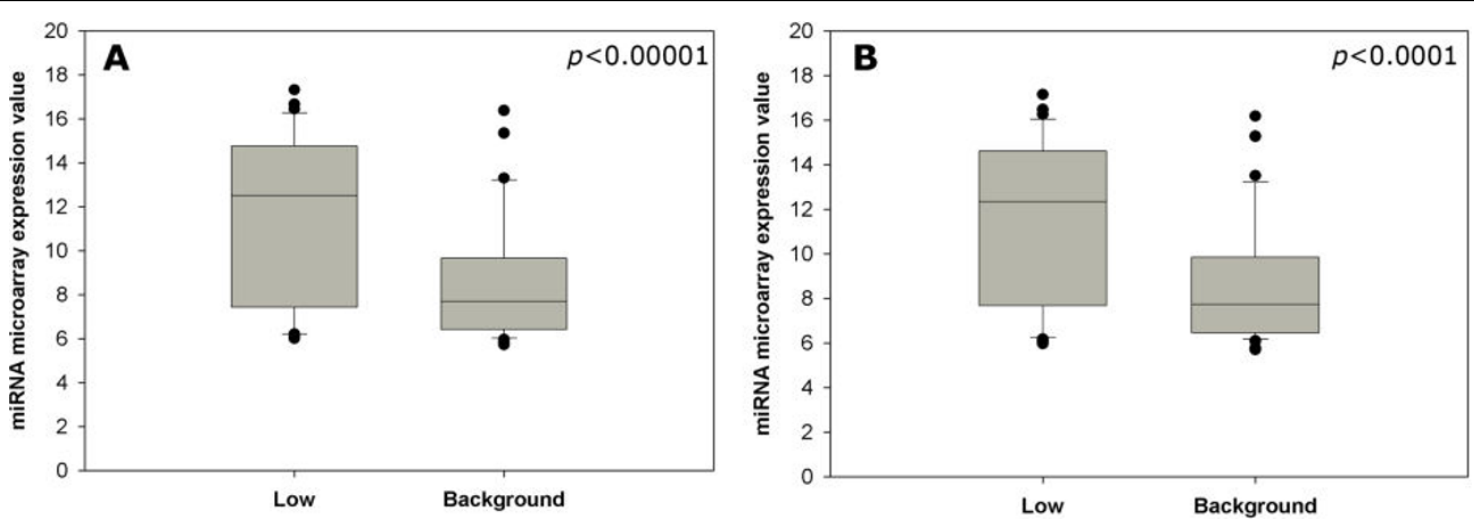

Figure 2 Association of miRNA expression with extent of predicted effect upon target mRNA expression in adult murine retina. Expression of those miRNAs with a significant effect $(p<0.1)$ upon target gene expression ('low' group) was significantly higher than that of those miRNAs with no predicted effects ('background' group). Microarray data from Loscher et al [13] was available for two strains of mouse, C57 (A) and 129 (B), and both showed a similar result. 


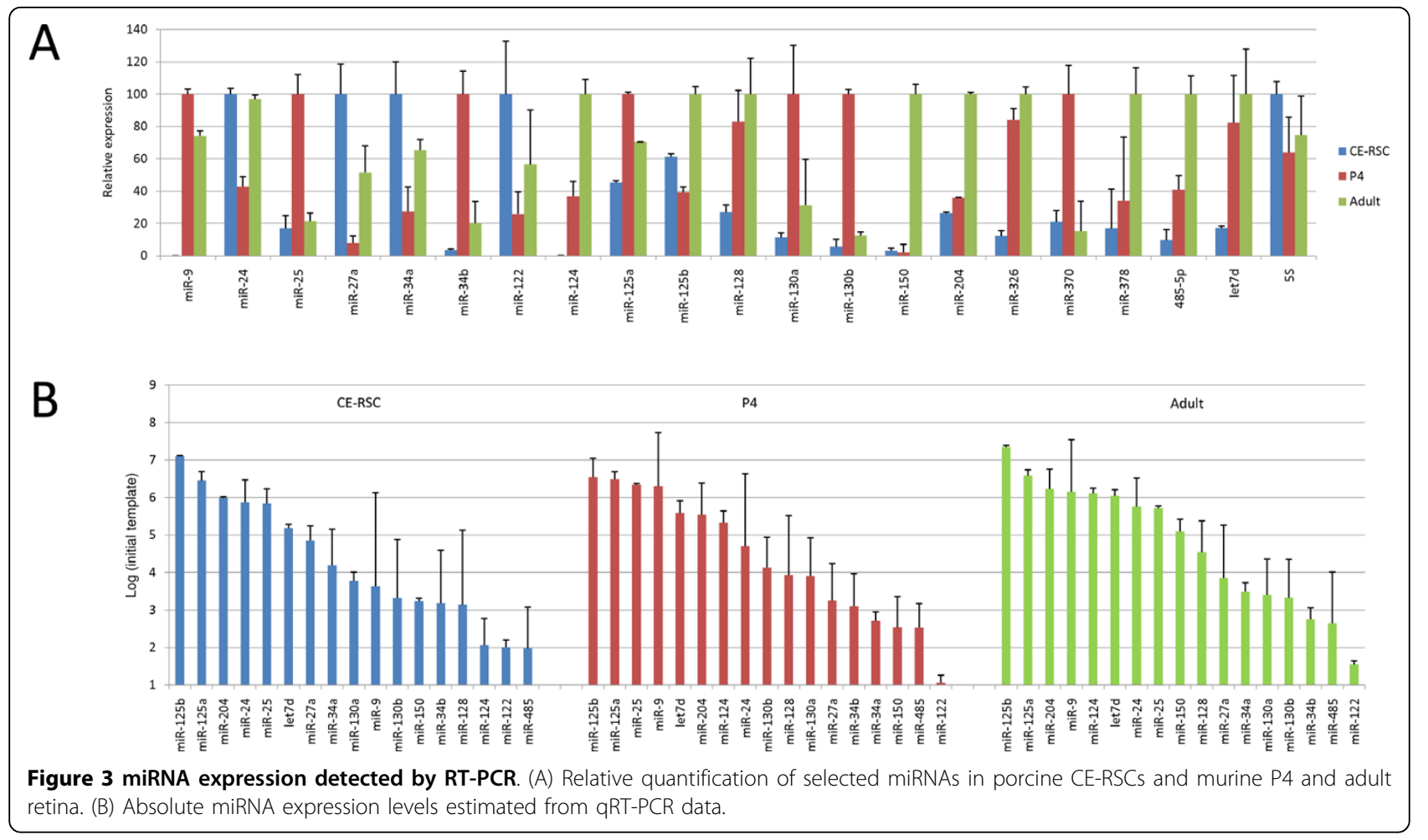

targeted by three miRNAs with the highest expression and greatest predicted effects (miR-124; miR-125 and miR-9.) were selected for validation: ACCN2; ETS1; KLF13; LIN28B; NFIB and SH2B3. Following transfection of HEK293 cells with a pool of miR-124, miR-125 and miR-9 miRNA mimics the mRNA expression of 5 of these 6 genes was significantly reduced (Figure 6). Comparison of the predicted miRNA target genes with those known to be involved in retinal function and disease [14] highlighted potential genes of interest (Table 3 and Additional file 3: Table S2). There was considerable overlap between known 'retinal genes' targeted by multiple miRNAs in $\mathrm{P} 4$ and adult retina. For example, a gene involved in the elongation of very long chain fatty acids (ELOVL4) is a predicted target of miRNAs with the most significant predicted effects on gene expression and the highest expression in RT-PCR assays. ELOVL4 has been implicated in Stargardts disease and macular dystrophy [32] and is expressed in photoreceptor inner segments [33], in agreement with the ISH localisation of miR-124 (Figure 5), its predicted regulator. Likewise, Neurocalcin delta (NCALD) is expressed in retinal amacrine and ganglion cells [34] in agreement with the expression of miR-204, one of its potential regulators [9].

To establish the cellular functions which are regulated by the miRNAs shown to affect mRNA expression, enrichment of functional annotation terms within the predicted target genes was assessed [35]. The genes with target sites for those miRNAs identified by our analyses were selected from the set of all genes with a conserved miRNA target site predicted by TargetScan; this list was therefore used as the background to assess enrichment (various categories, including many regulatory functions, are already enriched in this group in comparison to the whole genome; data not shown). In all the different tissue types at different developmental stages, genes with two or more predicted sites for candidate miRNAs affecting mRNA levels were enriched for annotations predominately relating to regulatory functions, notably gene transcription (Additional file 4: Table S3).

\section{Discussion}

miRNAs regulate mRNA expression in the retina

Gene expression is regulated by many factors at both transcriptional and posttranscriptional levels. The effect of miRNAs within these influences is detectable through analysis of microarray expression profiles; groups of mRNAs defined by presence of a putative target site for specific miRNAs were expressed at a significantly lower level than the group of non-target genes. These effects were observed in developing and adult retina and to a lesser extent in CE-RSCs. Not surprisingly, these effects were related to the expression level of the miRNA; those with extremely significant effects, such as miR125 , miR-124 and miR-9 were amongst the most highly expressed in the $\mathrm{P} 4$ and adult murine retina. The 


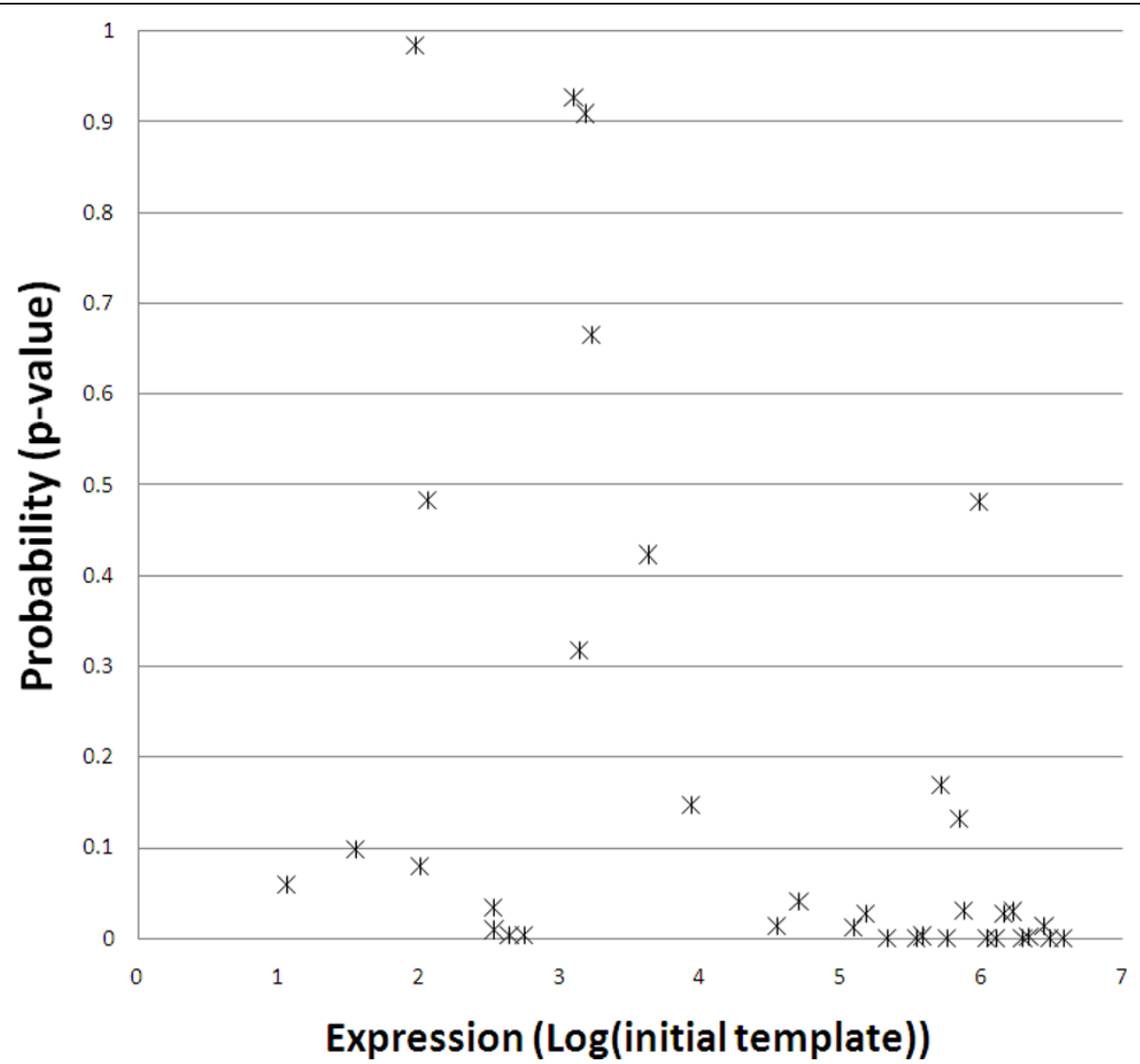

Figure 4 Comparision between the predicted effects of miRNAs and their expression as determined by RT-PCR. The estimated copy number (Log(initial template)) of each miRNA in a given sample is plotted against the probability (Wilcoxon ranked sum test) that it is having an effect upon target gene expression. The most highly expressed miRNAs have very significant effects upon predicted target gene expression and the overall correlation between miRNA expression and significance of effect upon target gene expression is significant ( $p=4.0 \mathrm{E}-04$;

Spearman rank correlation).

miRNA expression patterns determined in this study were consistent with previous reports. For example, miR-125, miR-124 and miR-9 have all been independently reported to be highly expressed in the retina [9-11]. The association between the expression level of a miRNA and its predicted effects on mRNA expression is robust because it was demonstrated for both our qRTPCR analysis of a relatively small number of miRNAs and for global miRNA expression profiles determined by other investigators [13].

Genes predicted to be targeted by multiple candidate miRNAs affecting mRNA levels are the best candidates for in vivo regulation by this mechanism. It is difficult to test this assertion in retinal cells, however the predicted effects on mRNA expression were observed for five of six genes in an in vitro model. This provides some support to the predictions of individual genes affected by miRNAs, at least for those targeted by multiple miRNAs with highly significant overall effects on mRNA expression,
The pattern of miRNA activity suggests a role in retinal differentiation

The predicted effects of miRNAs were less significant in mouse CE-RSCs than in the P4 and adult retina. miRNA expression was correspondingly lower, with only 4 of 20 miRNAs displaying highest expression in the CE-RSCs (although this may have been partly due to the porcine origin of the CE-RSCs used for RT-PCR analyses). The absolute levels of these miRNAs were also lower than those highly expressed in P4 and adult retina. This is consistent with reports that miRNA expression increases from very low levels at embryonic day 10 , when the retina is comprised of retinal progenitor cells with similar properties and gene expression patterns to CE-RSCs [36], to higher levels in the P1 and adult retina [11]. This pattern of miRNA expression and predicted effects supports a role for miRNAs in retinal differentiation, maturation and maintenance of the adult retina. A similar observation was noted by Wienholds and co-authors, when they 


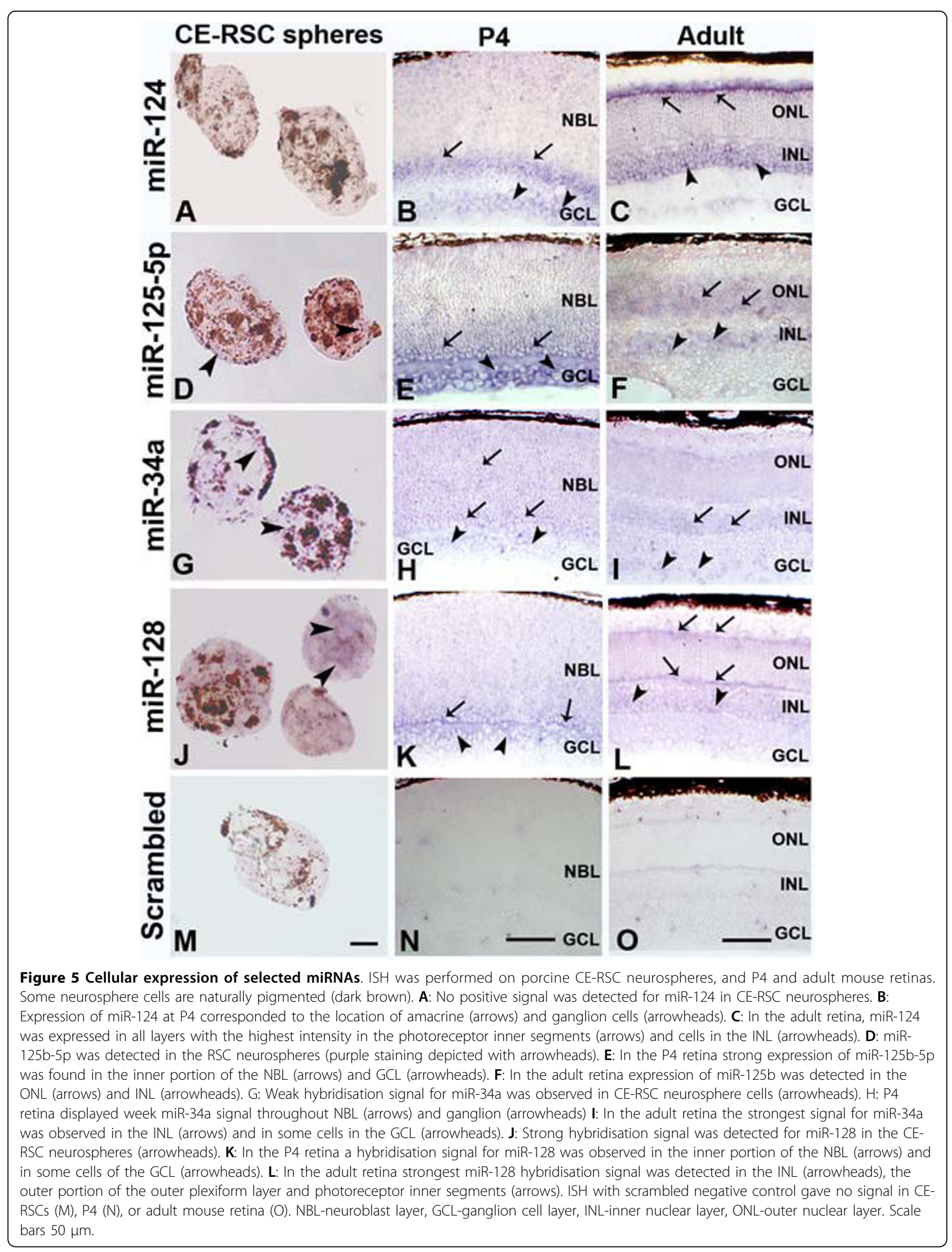


Table 2 Genes predicted to be targets of the candidate miRNAs affecting mRNA levels.

\begin{tabular}{|c|c|c|c|c|c|}
\hline CE-RSCs & & P4 & & Adult & \\
\hline Gene & miRNAs & Gene & miRNAs & Gene & miRNAs \\
\hline CUGBP2 & $\begin{array}{l}153 ; 24 ; 183 ; 378 ; 33 ; 30-3 p ; \\
342\end{array}$ & ACVR2A & $\begin{array}{l}\text { 27; 96; 29; 128; 196; 150; let-7/98; 124.1; } \\
\text { 125/351; 362; } 378\end{array}$ & ACVR2A & $\begin{array}{l}\text { 503; 27; 96; 448; 378; 29; 196; 125/351; } \\
\text { 150; 124.1; let-7/98 }\end{array}$ \\
\hline KPNA4 & $\begin{array}{l}\text { 142-5p; 33; 153; 378; let-7/ } \\
98 ; 183 ; 24\end{array}$ & TNRC6B & $\begin{array}{l}362 ; 184 ; 27 ; 124.1 ; 9 ; 204 / 211 ; 378 ; 485- \\
\text { 5p; 150; 29; } 22\end{array}$ & TNRC6B & $\begin{array}{l}\text { 150; 503; 378; 448; 9; 184; 485-5p; 29; } \\
\text { 204/211; 124.1; } 27\end{array}$ \\
\hline ZNF148 & $\begin{array}{l}\text { 183; 125/351; 370; 142-5p; } \\
24 ; 378 ; 153\end{array}$ & NFIB & $\begin{array}{l}125 / 351 ; 331 ; 22 ; 128 ; 485-5 p ; 124.1 ; 29 ; \\
27 ; 9 ; 24\end{array}$ & RICTOR & $\begin{array}{l}\text { 196; 448; 124.1; 96; 503; 326; 27; let-7/98; } \\
\text { 204/211; } 29\end{array}$ \\
\hline CLCN5 & $\begin{array}{l}\text { 30-3p; let-7/98; 378; 24; } \\
142-5 p ; 153\end{array}$ & ZNF148 & $\begin{array}{l}34 b ; 196 ; 204 / 211 ; 378 ; 124.1 ; 24 ; 128 ; \\
370 ; 125 / 351 ; 27\end{array}$ & CLCN5 & $\begin{array}{l}\text { 448; 503; 378; 9; 29; 24; let-7/98; 27; 485- } \\
5 p\end{array}$ \\
\hline CPEB4 & $\begin{array}{l}\text { 142-5p; 33; 342; 125/351; } \\
\text { 153; let-7/98 }\end{array}$ & MECP2 & $\begin{array}{l}\text { 34b; 22; 204/211; 378; let-7/98; 196; 326; } \\
\text { 96; } 124.1\end{array}$ & HMGA2 & $\begin{array}{l}\text { 196; 125/351; 204/211; 9; 485-5p; 503; } \\
\text { 150; 326; let-7/98 }\end{array}$ \\
\hline DAGLA & $\begin{array}{l}\text { 153; 183; 485-3p; 125/351; } \\
\text { 24; let-7/98 }\end{array}$ & $\begin{array}{l}\text { RP11- } \\
\text { 130N24.1 }\end{array}$ & $\begin{array}{l}\text { 362; 96; 9; 29; 125/351; 196; 27; 34b; } \\
124.1\end{array}$ & ZNF148 & $\begin{array}{l}\text { 204/211; 196; 124.1; 34b; 125/351; 24; } \\
448 ; 27 ; 378\end{array}$ \\
\hline EPHA4 & $\begin{array}{l}\text { 153; 125/351; 33; 30-3p; let- } \\
\text { 7/98; } 183\end{array}$ & SP1 & $\begin{array}{l}\text { 125/351; 29; 24; 27; 326; 378; 22; 128; } \\
124.1\end{array}$ & CPEB3 & 196; 125/351; 503; 29; let-7/98; 9; 27; 34b \\
\hline NARG1 & $\begin{array}{l}153 ; 378 ; 33 ; 342 ; 30-3 p ; \\
370\end{array}$ & ZBTB39 & $\begin{array}{l}\text { 9; 128; 485-5p; 22; 124.1; let-7/98; 27; } \\
331 ; 370\end{array}$ & MECP2 & $\begin{array}{l}\text { 326; 34b; 378; let-7/98; 96; 196; 124.1; } \\
\text { 204/211 }\end{array}$ \\
\hline PTPRD & $\begin{array}{l}\text { 485-3p; let-7/98; 30-3p; 153; } \\
24 ; 142-5 p\end{array}$ & ATXN1 & 125/351; 29; 9; 370; 326; 96; let-7/98; 34b & NFIB & $124.1 ; 448 ; 485-5 p ; 29 ; 9 ; 24 ; 27 ; 125 / 351$ \\
\hline ACVR2A & $\begin{array}{l}\text { 125/351; 153; 378; let-7/98; } \\
183\end{array}$ & CCNJ & $\begin{array}{l}\text { let-7/98; 196; 27; 128; 204/211; 370; 125/ } \\
351 ; 96\end{array}$ & $\begin{array}{l}\text { RP11- } \\
\text { 130N24.1 }\end{array}$ & $9 ; 125 / 351 ; 124.1 ; 27 ; 29 ; 196 ; 96 ; 34 b$ \\
\hline BTBD7 & $\begin{array}{l}342 ; 30-3 p ; 153 ; 378 ; 142- \\
5 p\end{array}$ & CLCN5 & 29; 9; 485-5p; 378; 24; 128; 27; let-7/98 & AKT3 & $124.1 ; 150 ; 503 ; 29 ; 448 ; 326 ; 125 / 351$ \\
\hline CPEB2 & $\begin{array}{l}\text { 153; 33; let-7/98; 183; 142- } \\
5 p\end{array}$ & CPD & $\begin{array}{l}\text { 196; 204/211; 370; 128; 150; let-7/98; } \\
331 ; 27\end{array}$ & ATXN1 & 34b; 125/351; 326; 96; let-7/98; 29; 9 \\
\hline $\mathrm{DDX} 3 \mathrm{X}$ & 30-3p; 33; 370; 183; 342 & CPEB3 & 128; 9; let-7/98; 125/351; 196; 29; 27; 34b & BRPF3 & $96 ; 326 ; 204 / 211 ; 125 / 351 ; 27 ; 503 ; 9$ \\
\hline E2F3 & $125 / 351 ; 153 ; 370 ; 378 ; 342$ & HMGA2 & $\begin{array}{l}\text { 196; 150; 485-5p; 204/211; 326; 125/351; } \\
\text { 9; let-7/98 }\end{array}$ & BSN & $448 ; 124.1 ; 24 ; 125 / 351 ; 150 ; 9 ; 503$ \\
\hline FBXO33 & $\begin{array}{l}; 142-5 p ; 30-3 p ; 342 ; 33 ; \\
153\end{array}$ & IGF2BP1 & 370; 331; let-7/98; 196; 24; 96; 326; 9 & CCND2 & 29; 196; 503; 96; let-7/98; 448; 124.1 \\
\hline MLL2 & $\begin{array}{l}; 142-5 p ; 342 ; \text { let-7/98; 370; } \\
33\end{array}$ & QKI & $\begin{array}{l}\text { 128; 485-5p; 9; 125/351; 370; 24; 124.1; } \\
27\end{array}$ & CCNJ & $\begin{array}{l}\text { 204/211; 27; 503; 196; 96; 125/351; let-7/ } \\
98\end{array}$ \\
\hline PDE4D & $; 183 ; 33 ; 24 ; 378 ; 485-3 p$ & RICTOR & $\begin{array}{l}\text { 27; 196; 96; 204/211; 29; 326; 124.1; let- } \\
\text { 7/98 }\end{array}$ & KLF13 & $9 ; 96 ; 125 / 351 ; 29 ; 448 ; 124.1 ; 378$ \\
\hline QKI & $\begin{array}{l}; 24 ; 370 ; 33 ; 125 / 351 ; 142- \\
5 p\end{array}$ & RIMS4 & $9 ; 96 ; 22 ; 27 ; 362 ; 127 ; 326 ; 331$ & MGA & $326 ; 124.1 ; 378 ; 29 ; 9 ;$ let-7/98; 485-5p \\
\hline RNF165 & $\begin{array}{l}\text {; let-7/98; 153; 24; 33; 142- } \\
5 p\end{array}$ & STC1 & $\begin{array}{l}\text { 485-5p; 124.1; 9; 125/351; 22; 378; 34b; } \\
96\end{array}$ & ONECUT2 & 27; 29; let-7/98; 485-5p; 9; 96; 503 \\
\hline RSBN1 & ; 342; 183; 153; 378; 485-3p & BRPF3 & $27 ; 9 ; 96 ; 128 ; 125 / 351 ; 204 / 211 ; 326$ & PAPPA & 27; 96; 150; let-7/98; 503; 448; 326 \\
\hline SETD7 & $\begin{array}{l}; 485-3 p ; 153 ; 33 ; 125 / 351 ; \\
342\end{array}$ & CPEB4 & 362; 96; 125/351; 128; 9; 27; let-7/98 & PTPRD & 24; 124.1; 204/211; 29; 503; let-7/98; 448 \\
\hline SIX4 & $\begin{array}{l}; 153 ; 378 ; 33 ; 30-3 p ; 142- \\
5 p\end{array}$ & $D C X$ & 27; let-7/98; 128; 29; 362; 9; 96 & QKI & $125 / 351 ; 124.1 ; 9 ; 503 ; 24 ; 485-5 p ; 27$ \\
\hline SLC4A4 & $\begin{array}{l}\text {; 153; 125/351; 370; 142-5p; } \\
\text { let-7/98 }\end{array}$ & DTNA & $9 ; 124.1 ; 378 ; 22 ; 24 ; 27 ; 128$ & RNF165 & 124.1; 448; let-7/98; 485-5p; 150; 29; 24 \\
\hline SOX11 & $\begin{array}{l}; 125 / 351 ; 153 ; 33 ; 142-5 p ; \\
485-3 p\end{array}$ & FRMD4A & $29 ; 9 ; 204 / 211 ; 128 ; 124.1 ; 96 ; 34 b$ & SP1 & $326 ; 124.1 ; 125 / 351 ; 29 ; 378 ; 27 ; 24$ \\
\hline SP1 & $\begin{array}{l}; 24 ; 125 / 351 ; 485-3 p ; 378 ; \\
33\end{array}$ & GABBR2 & $128 ; 9 ; 22 ; 378 ; 326 ; 204 / 211 ; 370$ & STC1 & 485-5p; 378; 34b; 124.1; 9; 125/351; 96 \\
\hline STC1 & $\begin{array}{l}; 125 / 351 ; 30-3 p ; 142-5 p ; \\
378 ; 183\end{array}$ & ISL1 & $27 ; 29 ; 128 ; 96 ; 9 ; 362 ; 378$ & ZFHX4 & $204 / 211 ; 96 ; 503 ; 485-5 p ; 448 ; 27 ; 9$ \\
\hline THRAP1 & $\begin{array}{l}; 485-3 p ; 142-5 p ; 183 ; 153 ; \\
24\end{array}$ & KLF12 & 34b; 370; 204/211; 124.1; 29; 9; 27 & ACCN2 & $9 ; 29 ; 326 ; 125 / 351 ; 124.1 ; 27$ \\
\hline YOD1 & $\begin{array}{l}\text {; let-7/98; 183; 24; 30-3p; } \\
125 / 351\end{array}$ & MGA & 378; 485-5p; 326; 29; let-7/98; 9; 124.1 & APPBP2 & 9; 448; 378; 27; let-7/98; 29 \\
\hline
\end{tabular}


Table 2: Genes predicted to be targets of the candidate miRNAs affecting mRNA levels. (Continued)

\begin{tabular}{llllll}
\hline ZFPM2 & $; 183 ; 142-5 p ; 485-3 p ; 153 ;$ & MITF & $27 ; 331 ; 34 b ; 378 ; 124.1 ; 485-5 p ; 96$ & CPEB4 & $448 ; 9 ; 27 ; 125 / 351 ; 96 ;$ let-7/98 \\
& 33 & & & & \\
\hline ARID4B & $; 370 ; 183 ; 378 ; 142-5 p$ & MMP16 & $150 ; 27 ; 370 ; 24 ; 124.1 ; 9 ; 96$ & CUGBP2 & $96 ; 326 ; 34 b ; 378 ; 196 ; 24$ \\
\hline
\end{tabular}

The top 30 genes in each tissue ranked by number of different miRNAs predicted to target them. Genes for which certain miRNA interactions were assessed experimentally are marked in bold. The full list of genes targeted by at least one of the candidate miRNAs affecting mRNA levels is shown in Table S2.

were able to detect only a few miRNAs during early zebrafish development [37].

Although generally lower than in retina, miRNA expression was described for the first time in this study in CE-RSCs. Human and porcine eyes are similar in terms of morphology and physiology. We have previously characterised porcine CE-RSCs [38] and therefore, although the availability of mouse expression data for CE-RSCs, P4 and adult retina made it the choice for in silico analyses, porcine CE-RSCs were used to confirm expression of predicted miRNAs. CE-RSCs from various species have been shown to have very similar properties and gene expression patterns [38-41] Of the 4 miRNAs expressed most highly in CE-RSCs according to RT-PCR, miR-24 was also predicted to have a significant effect $(\mathrm{p}<0.05)$ upon mRNA expression and miR122 had $p=0.08$. It has recently been shown that miR24a represses apoptosis and is required for proper retinal development [42]. These miRNAs could also play a role in maintaining the progenitor cell state, as has been shown in other tissues; over-expression of miR-24 causes a delay in maturation of hematopoietic progenitor cells [43] and over-expression of miR-122 delays differentiation of human embryonic stem cells [44].
Many of the specific miRNAs shown to affect mRNA expression in the $\mathrm{P} 4$ and adult retina have previously been implicated in neuronal differentiation. For example, miR-124 has been associated with the transition from neural progenitor to differentiated neuron in the zebrafish brain [45]. In mouse brain miR-124 expression is restricted to mature neurons [46] and it promotes neuronal differentiation by triggering brain-specific alternative pre-mRNA splicing [47]. The reported absence of miR-124 in neural and retinal stem/progenitor cells in vivo $[9,48,49]$ concurs with the lack of detectable expression in the CE-RSC spheres. Expression of miR-124 in the immature retina (P4) was lower than that in the adult retina and the ISH signal at P4 mainly corresponded to early differentiating neurons, retinal ganglion and amacrine cells. Our ISH for miR-124 in the adult retina confirmed previous reports [9] and showed miR-124 expression in all retinal layers, with particularly high levels in photoreceptor inner segments.

miR-9 promotes progression of neurogenesis in the zebrafish brain [50]. Expression of miR-9 was not detected in CE-RSCs, but in contrast to miR-124 it peaked in the $\mathrm{P} 4$ retina. This pattern is in agreement with Xu et al [11], who reported a very low level of miR-9 expression at E10 which gradually increased and

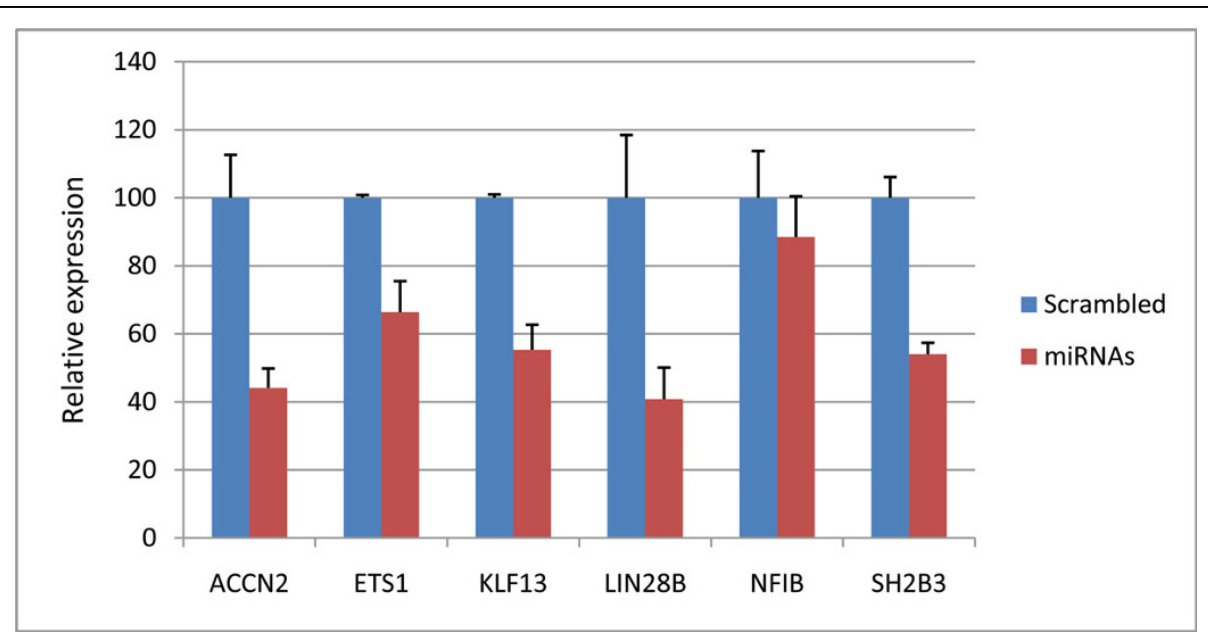

Figure 6 Overexpression of miRNAs reduces predicted target mRNA levels. Pools of miR-124, miR-125 and miR-9 miRNA mimics (miRNAs) or scrambled controls (Scrambled) were transfected into HEK293 cells. The mRNA expression of six genes predicted to be targeted by these three miRNAs was subsequently assessed by qRT-PCR. The graph shows the significant $(P<0.01)$ reduction in expression of ACCN2, ETS1, KLF13, LIN28B and SH2B3 following transfection with miRNAs relative to the scrambled control (error bars show standard deviation). There was no significant difference in expression of NFIB. 
Table 3 Predicted target genes known to be involved in retinal function and disease.

\begin{tabular}{|c|c|c|c|c|c|}
\hline CE-RSCs & & $\mathrm{P} 4$ & & Adult & \\
\hline 4: NLK & 1: NEFL & 6: CAMTA1 & 1: COL18A1 & 5: NCOR2 & 1: DDIT4 \\
\hline 3: DMD & 1: PCDHGC3 & 6: NCOR2 & 1: COL2A1 & 4: CAMTA1 & 1: DUSP1 \\
\hline 2: ADD1 & 1: PPP1R3F & 5: ELOVL4 & 1: DUSP1 & 4: ELOVL4 & 1: FAM57B \\
\hline 2: CAMTA1 & 1: PSAP & 5: NCALD & 1: FAM57B & 4: NCALD & 1: H2AFZ \\
\hline 2: GNB1 & 1: RARB & 4: NLK & 1: H2AFZ & 4: NLK & 1: HSP90AB1 \\
\hline 2: GPX3 & 1: RARG & 4: RARG & 1: IGFBP5 & 4: TP53INP2 & 1: IGFBP5 \\
\hline 2: GRIA4 & 1: RDH10 & 4: TSPAN9 & 1: IMPDH1 & 4: TSPAN9 & 1: IMPDH1 \\
\hline 2: HSPA8 & 1: RGS16 & 3: FZD4 & 1: KIAA0143 & 3: DMD & 1: KIF1B \\
\hline 2: JAG1 & 1: $\mathrm{RHO}$ & 3: TEAD1 & 1: KIF1B & 3: FZD4 & 1: MAK \\
\hline 2: PAX2 & 1: RIMS1 & 3: TP53INP2 & 1: MAK & 3: JAG1 & 1: MAPT \\
\hline 2: RB1 & 1: SGIP1 & 3: ZNF385 & 1: MAPT & 3: RARG & 1: PCDHGC3 \\
\hline 2: SLC17A7 & 1: SLC12A5 & 2: CFL1 & 1: PAX2 & 3: TEAD1 & 1: PITPNA \\
\hline 2: TEAD1 & 1: SLC25A18 & 2: CSDA & 1: PITPNA & 2: CSDA & 1: PPP1R3F \\
\hline 1: APP & 1: SPP1 & 2: DMD & 1: PPP1R3F & 2: GPX3 & 1: PRELP \\
\hline 1: ATP8B1 & 1: STAC2 & 2: GPX3 & 1: PRELP & 2: GRIA4 & 1: PSAP \\
\hline 1: BHLHB3 & 1: SYP & 2: GRIA4 & 1: PSAP & 2: PAX2 & 1: RARA \\
\hline 1: CAMSAP1 & 1: TFAP2B & 2: JAG1 & 1: RARB & 2: SLC12A5 & 1: RARB \\
\hline 1: CCNI & 1: TP53INP2 & 2: RARA & 1: RB1 & 2: SLC17A7 & 1: RB1 \\
\hline 1: CFL1 & 1: TSPAN9 & 2: RIMS1 & 1: RDH10 & 2: TRPM3 & 1: RDH10 \\
\hline 1: CLASP2 & 1: USH2A & 2: SGIP1 & 1: RGS16 & 2: ZNF385 & 1: RGS16 \\
\hline 1: COL2A1 & 1: ZNF385 & 2: SLC12A5 & 1: RGS9 & 1: ACTB & 1: RGS9 \\
\hline 1:CP & & 2: SLC17A7 & 1: $\mathrm{RHO}$ & 1: ACTG1 & 1: $\mathrm{RHO}$ \\
\hline 1: DDIT4 & & 2: TAGLN & 1: RS1 & 1: ADD1 & 1: RIMS1 \\
\hline 1: DUSP1 & & 2: TRPM3 & 1: SLC1A3 & 1: AFF1 & 1: RS1 \\
\hline 1: EEF1A1 & & 1: ACTB & 1: SLC25A18 & 1: ANXA2 & 1: SGIP1 \\
\hline 1: EIF1 & & 1: ACTG1 & 1: SMOC2 & 1: ATP8B1 & 1: SLC25A18 \\
\hline 1: ELOVL4 & & 1: AFF1 & 1: SPARC & 1: ATXN7 & 1: SMOC2 \\
\hline 1: FZD4 & & 1: ANXA2 & 1: SPG20 & 1: CAMK2D & 1: SPARC \\
\hline 1: HSP90AB1 & & 1: ATP8B1 & 1: STAC2 & 1: CCNI & 1: SPG20 \\
\hline 1: IGFBP5 & & 1: ATXN7 & 1: SYP & 1: CFL1 & 1: STAC2 \\
\hline 1: KIF1B & & 1: CAMK2D & 1: TFAP2B & 1: CLASP2 & 1: SYP \\
\hline 1: MSH6 & & 1: CCNI & & 1: COL11A1 & 1: TAGLN \\
\hline 1: NCALD & & 1: CLASP2 & & 1: COL18A1 & 1: TFAP2B \\
\hline 1: NCOR2 & & 1: COL11A1 & & 1: COL2A1 & \\
\hline
\end{tabular}

Genes predicted to be targeted by one or more candidate miRNA affecting mRNA levels were compared with genes implicated in retinal function[14]. The overlapping genes are listed, with the number of different miRNAs predicted to target them followed by the gene symbol.

peaked at P10, being lower in the adult retina. Notably, the transcription factor Hes1, which maintains retinal progenitor pools during development is a predicted target for miR-9 [50]. Similarly to retinal progenitor cells, high levels of Hes1 mRNA are found in CE-RSC spheres (Yanagi et al 2006, our unpublished data). Decrease of miR-9 expression past P10 correlates with the completion of retinal cell differentiation. miR-125 is another miRNA with highly significant predicted effects upon mRNA expression and the high expression levels for miR-125a and miR-125b detected by RT-PCR are in agreement with previous miRNA array data $[8,11]$.
Together with miR-124 and miR-9, miR-125b is also induced during neural differentiation of embryonic stem cells [51].

miRNAs differ in their effects upon mRNA turnover and translational repression

Our results suggest that, although many miRNAs are present in the retina, only a few affect mRNA levels sufficiently to have a detectable influence on target gene expression. Despite conclusive evidence of the high expression of miRNAs such as miR-181, -182 and -183 in the retina $[8,9]$ the genes targeted by these miRNAs did not show significant down regulation at the mRNA 
level in our analysis. Conversely miR-122, which has previously been shown to direct mRNA cleavage [21], was expressed at a low level, but had a significant predicted effect upon target gene expression in several samples (combined $\mathrm{p}=0.08$ ). Interestingly, miR-125b, one of the miRNAs with the strongest predicted effect upon mRNA levels, has been shown to accelerate deadenylation leading to rapid mRNA decay [52]. It is now accepted that miRNAs can mediate both translational repression and accelerated mRNA turnover [53]. One explanation for the detection of the effect of some highly expressed retinal miRNAs upon mRNA levels and not others could be that they are acting preferentially at the level of mRNA turnover.

\section{Conclusions}

The evidence presented in this study suggests that many miRNAs affect the expression levels of their target mRNAs during retinal development. The enrichment of the predicted target genes of these miRNAs for regulatory functions is in keeping with the proposed regulatory role of miRNAs. The lack of a mRNA 'signature' for other miRNAs which are also known to be highly expressed in the retina, suggests that certain miRNAs are less active at the mRNA level and perhaps act predominately upon translation. The identity and expression pattern of those miRNAs which were detected by analysis of target gene expression, such as miR-124, miR-125 and miR-9, provides further evidence that miRNAs play a central role in neuronal differentiation during retinal development.

\section{Methods}

\section{Animal procedures}

All animal procedures were performed in compliance with the UK Animals (Scientific Procedures) Act 1986. Adult mice were euthanised in a $\mathrm{CO}_{2}$ chamber and $\mathrm{P} 4$ neonatal mice were lethally anesthetised by intra-peritoneal (IP) injection of an overdose of pentobarbitone. Eyes were enucleated and either processed for ISH or the retinas dissected and snap frozen in liquid nitrogen for RNA isolation.

\section{Isolation and culture of CE-RSCs}

Mixed sex White Landrace pigs were obtained from the Department of Agriculture and Rural Development Northern Ireland, Hillsborough, UK. CE-RSCs were isolated and grown as described previously [38]. Briefly, 12 week old pigs were lethally anesthetised, eyes were enucleated and placed into oxygenated artificial cerebral spinal fluid [aCSF: $124 \mathrm{mM} \mathrm{NaCl}, 5 \mathrm{mM} \mathrm{KCl}, 1.3 \mathrm{mM}$ $\mathrm{MgCl} 2,26 \mathrm{mM} \mathrm{NaHCO} 3$, and $10 \mathrm{mM}$ D-glucose, (Sigma-Aldrich, Poole, UK)]. A strip of ciliary body was dissected and enzymatically digested in Hanks' Balanced Salt Solution (HBSS) containing $2 \mathrm{mg} / \mathrm{ml}$ dispase
(Sigma-Aldrich, Poole, UK) for 20 minutes at $37^{\circ} \mathrm{C}$, followed by digestion in EBSS containing $1.33 \mathrm{mg} / \mathrm{ml}$ trypsin, $0.67 \mathrm{mg} / \mathrm{ml}$ hyaluronidase and 78 units $/ \mathrm{ml}$ collagenase (Sigma-Aldrich, Poole, UK) for $20 \mathrm{~min}$ at $37^{\circ} \mathrm{C}$. The supernatant was decanted and replaced with serum-free medium (SFM, DMEM/F12 (1:1) containing $0.6 \%(\mathrm{w} / \mathrm{v})$ glucose, $2 \mathrm{mM}$ glutamine, $5 \mathrm{mM}$ HEPES buffer, $2 \%(\mathrm{v} / \mathrm{v}) \mathrm{B} 27,100$ units/ml penicillin and 100 units/ $\mathrm{ml}$ streptomycin) with $1 \mathrm{mg} / \mathrm{ml}$ trypsin inhibitor (Invitrogen, Paisley UK). The cellular debris was gently triturated and dissociated into single cells with a firepolished pipette. Cells were pelleted at $800 \mathrm{rpm}$ for 10 minutes, resuspended in SFM and passed through a 40 $\mu \mathrm{m}$ cell strainer (BD Biosciences, USA). Cells were counted and plated at a density of $3 \times 10^{4}$ cells $/ \mathrm{ml}$ in SFM supplemented with $20 \mathrm{ng} / \mathrm{ml}$ of epidermal growth factor (EGF) and $10 \mathrm{ng} / \mathrm{ml}$ basic fibroblast growth factor (bFGF) (Invitrogen, Paisley, UK). After 7 days newly formed sphere colonies were collected, pelleted at 800 rpm for 10 minutes and digested in Accumax cell counting solution (ICT, San Diego, USA) for $20 \mathrm{~min}$ at RT and mechanically dissociated into single cells by pipetting. Cells were washed once in SFM and plated at a density of $3 \times 10^{4}$ cells $/ \mathrm{ml}$. After 7 days secondary spheres were collected.

\section{miRNA target confirmation}

HEK293-T cells were transfected at 80\% confluency with miRNA mimics (Qiagen, Crawley, UK) using Turbofect transfection reagent (Fermentas, York, UK). Cells were collected for RNA isolation at 48 hours post transfection.

\section{RNA isolation}

For mRNA analyses RNA was extracted using an RNeasy Micro Kit with on column DNAse digestion (Qiagen, West Sussex, UK) according to the manufacturer's protocol. For miRNA analyses total RNA was extracted using a mirVana extraction kit (Ambion, Foster City, CA) according to the manufacturer's protocol. mRNA microarray analysis and gene expression datasets RNA samples from retinas of three P4 mice were labeled and hybridized to GeneChip ${ }^{\circ}$ 430A 2.0 mouse microarrays (Affymetrix, Santa Clara, Ca.) according to the manufacturer's protocols. Raw data were analysed using the Affymetrix MAS 5.0 algorithm and the results deposited in NCBI's Gene Expression Omnibus (GEO) $[54,55]$. Publicly available mRNA expression data were downloaded from GEO. All the data were generated from Affymetrix genechips. Samples analysed on the MOE430A platform were available for CE-RSC and are directly comparable with the Mouse 430A 2.0 platform used for the P4 retina samples $(\sim 14,000$ well characterised transcripts). Data from the MOE430B platform ( 22,000 transcripts) was also available for several CERSC samples. The Mouse430_2 platform used for adult 
Table 4 Gene expression datasets.

\begin{tabular}{|c|c|c|c|}
\hline $\begin{array}{l}\text { GEO } \\
\text { accession }\end{array}$ & Type & Organism & Tissue \\
\hline GSM87191 & mRNA & Human & $\begin{array}{l}\text { Retinal spheres from ciliary } \\
\text { epithelium of adult eye }\end{array}$ \\
\hline GSM87193 & mRNA & Human & $\begin{array}{l}\text { Retinal spheres from ciliary } \\
\text { epithelium of adult eye }\end{array}$ \\
\hline GSM87194 & mRNA & Human & $\begin{array}{l}\text { Retinal spheres from ciliary } \\
\text { epithelium of adult eye }\end{array}$ \\
\hline GSM87195 & mRNA & Mouse & $\begin{array}{l}\text { Retinal spheres from ciliary } \\
\text { epithelium of adult eye }\end{array}$ \\
\hline GSM87196 & mRNA & Mouse & $\begin{array}{l}\text { Retinal spheres from ciliary } \\
\text { epithelium of adult eye }\end{array}$ \\
\hline GSM87197 & mRNA & Mouse & $\begin{array}{l}\text { Retinal spheres from ciliary } \\
\text { epithelium of adult eye }\end{array}$ \\
\hline GSM87198 & mRNA & Mouse & $\begin{array}{l}\text { Retinal spheres from ciliary } \\
\text { epithelium of adult eye }\end{array}$ \\
\hline GSM87199 & mRNA & Human & $\begin{array}{l}\text { Retinal spheres from ciliary } \\
\text { epithelium of adult eye }\end{array}$ \\
\hline GSM87200 & mRNA & Human & $\begin{array}{l}\text { Retinal spheres from ciliary } \\
\text { epithelium of adult eye }\end{array}$ \\
\hline GSM87201 & mRNA & Mouse & $\begin{array}{l}\text { Retinal spheres from ciliary } \\
\text { epithelium of adult eye }\end{array}$ \\
\hline GSM87202 & mRNA & Mouse & $\begin{array}{l}\text { Retinal spheres from ciliary } \\
\text { epithelium of adult eye }\end{array}$ \\
\hline $\begin{array}{l}\text { GSM32153 } \\
{[64]}\end{array}$ & mRNA & Mouse & Adult Retina \\
\hline $\begin{array}{l}\text { GSM81691 } \\
{[65]}\end{array}$ & mRNA & Mouse & Adult Retina \\
\hline $\begin{array}{l}\text { GSM92629 } \\
{[66]}\end{array}$ & mRNA & Mouse & Adult Retina \\
\hline GSM107514 & mRNA & Mouse & Adult Retina \\
\hline GSM419995* & mRNA & Mouse & P4 Developmental Retina \\
\hline GSM419996* & mRNA & Mouse & P4 Developmental Retina \\
\hline GSM419997* & mRNA & Mouse & P4 Developmental Retina \\
\hline
\end{tabular}

The mRNA expression datasets analysed to detect the effect of miRNAs were downloaded from Gene expression omnibus (GEO) or created in-house $(*$ ). The GEO accession numbers and details are listed. Numbers indicate associated references.

retinal expression interrogated all the transcripts in the $A$ and B platforms. The tissues and GEO sample accession numbers are listed in Table 4.

\section{miRNA target predictions}

Predictions from TargetScan $[23,24]$ were used because we have previously demonstrated the ability of this algorithm to predict known tissue-specific miRNAs [29]. TargetScan's requirement for a perfect match to the seed region and cross-species conservation reduces the false-positive rate $[24,25,56]$. By minimising background, use of this algorithm maximises the ability to detect effects on expression of real miRNA target genes. Complete miRNA datasets published by Lewis et al. [24] were downloaded from the TargetScan website (version 3.1) [57]. For controls, 5 random datasets were generated for each of the gene expression datasets. For each of the random sets, the same numbers of target genes as predicted by TargetScan were randomly assigned to each of the miRNAs. The relationships between candidate miRNAs predicted to affect mRNA levels in the retina and their target genes were analysed using Microsoft Access and 'targets of conserved families' from Targetscan version 4.2. Functional characterisation of predicted target genes was performed using the DAVID bioinformatics database [35].

\section{Bioinformatic analysis of target mRNA levels}

The relative expression of the predicted target gene sets for each miRNA were compared as described previously using stand alone Java and R [58] programs in conjunction with MS Access and MS Excel [29]. Only single gene-specific Affymetrix probesets (suffix_at) were considered and only those expressed in each dataset analysed (designated by a 'present' call if available, or alternatively by a signal strength greater than the median value). Probeset IDs were converted to their cognate Gene Symbols, using the Biomart online suite [59]. For each mRNA expression dataset (Table 4), lists of expressed genes targeted by each miRNA family and their respective expression levels were compiled. The mean expression level was calculated for genes represented by $>1$ probeset to provide the 'Average Target Gene Signal'. Only miRNAs with $>50$ predicted targets were considered. The expression values of the predicted targets of a specific miRNA in each individual dataset were compared with the set of expression values in that dataset of all the genes predicted to be targeted by miRNAs. To determine whether there was a significant difference between the medians of the ranked gene expression values of the two sets, the nonparametric one-sided Wilcoxon rank sum test was employed. Fisher's combined probability test was used to calculate a composite test statistic from the individual p-values associated with the multiple expression datasets from CE-RSCs, P4 or adult retina[60]. For every miRNA with a combined $\mathrm{p}<0.05$ we considered that the expression of the set of genes targeted by that miRNA in that tissue was significantly less than the average expression of all the targeted genes.

\section{RT-PCR}

RT for detection of mRNAs was performed with $1 \mu \mathrm{g}$ of RNA using random hexamers and SuperscriptIII (Invitrogen, Paisley, UK). Specific miRNAs were detected using a modified version of the method described by Shi and Chiang [61], in which mature miRNAs are polyadenylated and target sequences for a reverse primer are subsequently incorporated into cDNA by use of an oligo $\mathrm{dT}$ adapter. One microgram of RNA was polyadenylated using poly(A) polymerase (PAP; Ambion, Foster City, $\mathrm{CA})$ at $37^{\circ} \mathrm{C}$ for 1 hour in a $25-\mu \mathrm{l}$ reaction mixture. RNAs were then reverse transcribed with $200 \mathrm{U}$ reverse 
Table 5 Sequences of primers and ISH probes.

\begin{tabular}{|c|c|}
\hline & DNA oligonucleotides \\
\hline Name & 5'-3' nucleotide sequence \\
\hline Let-7d & AGAGGTAGTAGGTTGCATAGT \\
\hline miR-9 & TCTTTGGTTATCTAGCTGTATGA \\
\hline miR-24 & TGGCTCAGTTCAGCAGGAACAG \\
\hline miR-25 & CATTGCACTTGTCTCGGTCTGA \\
\hline$\overline{\mathrm{miR}-27 a}$ & TTCACAGTGGCTAAGTTCCGC \\
\hline$\overline{\mathrm{miR}-34 a}$ & TGGCAGTGTCTTAGCTGGTTGTT \\
\hline miR-34b & TAGGCAGTGTAATTAGCTGATTG \\
\hline$\overline{m i R-122}$ & TGGAGTGTGACAATGGTGTTTG \\
\hline miR-124 & TAAGGCACGCGGTGAATGCC \\
\hline miR-128 & TCACAGTGAACCGGTCTCTTTT \\
\hline miR-125a-5p & TCCCTGAGACCCTTTAACCTGTGA \\
\hline miR-125b-5p & TCCCTGAGACCCTAACTTGTGA \\
\hline miR-130a & CAGTGCAATGTTAAAAGGGCAT \\
\hline miR-130b & CAGTGCAATGATGAAAGGGCAT \\
\hline miR-150 & TCTCCCAACCCTTGTACCAGTG \\
\hline miR-204 & TTCCCTITGTCATCCTATGCCTG \\
\hline miR-326 & CCTCTGGGCCCTTCCTCCAGT \\
\hline$\overline{\mathrm{miR}-370}$ & GCCGGCTGGGGTGGAACGTGGTT \\
\hline$\overline{\mathrm{miR}-378}$ & CTCCTGACTCCAGGTCCTGTGT \\
\hline miR-485-5p & AGAGGCTGGCCGTGATGAATTC \\
\hline Poly (T) adapter & $\begin{array}{l}\text { GCGAGCACAGAATTAATACGACTCA } \\
\text { CTATAGGTTITITITITTWN }\end{array}$ \\
\hline Reverse RACE & GCGAGCACAGAATTAATACGAC \\
\hline$\overline{\text { ETS1F }}$ & CCAGACAGACACCTTGCAGA \\
\hline$\overline{\text { ETS1R }}$ & TGAGGCGATCACAACTATCG \\
\hline KLF13F & GAAGCACAAGTGCCACTACG \\
\hline$\overline{\text { KLF13R }}$ & GGCAGCTGAACTTCTTCTCG \\
\hline$\overline{N F I B F}$ & AGCTGCTGGAAGTCGAACAT \\
\hline$\overline{\mathrm{NFIBR}}$ & TGAAGGTGGAGGTGGAGTTC \\
\hline LIN28BF & AAGGCCTTGAGTCAATACGG \\
\hline LIN28BR & CACTTCTTTGGCTGAGGAGG \\
\hline SH2B3F & CTGGAGCTCTTCGACCCAC \\
\hline SH2B3R & ATGTCTGTCCGGTCCTTCAC \\
\hline ACCN2F & AGCTGTTACCATGGACTCGG \\
\hline$\overline{A C C N 2 R}$ & CACGCAGTACTCCTGGTCCT \\
\hline
\end{tabular}

in situ probes

\begin{tabular}{ll}
\hline Name & Sequence (enhanced with LNA) 5'-3' \\
\hline mmu-miR-124 & GGCATTCACCGCGTGCCTTA \\
\hline mmu-miR-34a & AACAACCAGCTAAGACACTGCCA \\
\hline mmu-miR-128 & AAAAGAGACCGGTTCACTGTGA \\
\hline mmu-miR-125b- & TCACAAGTTAGGGTCTCAGGGA \\
\hline mmu-miR-378 & CCTTCTGACTCCAAGTCCAGT \\
\hline mmu-miR-122 & CAAACACCATTGTCACACTCCA \\
\hline Scrambled-miR & TTCACAATGCGTTATCGGATGT
\end{tabular}

Oligonucleotide primers and in situ probes from the miRCURY' ${ }^{\mathrm{TM}}$ LNA Detection system (Exiqon, Vedbaek, Denmark). transcriptase (SuperScript III; Invitrogen, Paisley, UK) and $0.5 \mu \mathrm{g}$ poly $(\mathrm{T})$ adapter (3' rapid amplification of complementary DNA ends (RACE) adapter in the FirstChoice RLM-RACE kit; Ambion). Primers for specific miRNAs were based on miRNA sequences obtained from miRBase [62,63] (Table 5). The reverse primer was the 3' adapter primer (3' RACE outer primer in the FirstChoice RLM-RACE kit; Ambion).

PCR was performed for 45 cycles with denaturation at $94^{\circ} \mathrm{C}$ for 30 seconds, annealing at $55^{\circ} \mathrm{C}$ for 30 seconds, and extension at $72^{\circ} \mathrm{C}$ for 30 seconds (LightCycler 480: Roche, Mannheim, Germany). PCR products were analyzed by polyacrylamide gel electrophoresis $(20 \%$; Invitrogen) to confirm the predicted size (approximately 60 $\mathrm{bp}$, including mature miRNA and adapter sequences).

Relative RNA expression was determined by measuring the concentration of template in each sample at the threshold cycle $(\mathrm{Ct})$ from a standard curve (Log concentration against $\mathrm{Ct}$ ) generated from dilutions of a pooled cDNA sample. Relative expression determined by an alternative method employing delta $\mathrm{Ct}$ values and efficiency values calculated from a standard curve gave very similar results (Additional file 2: Figure S1). Starting template copy number was estimated from $\mathrm{Ct}$ values using the equation: $\mathrm{R}_{0}=\mathrm{R}_{\mathrm{Ct}} /(1+\mathrm{E})^{\mathrm{Ct}}$ where $\mathrm{Ct}$ is the threshold cycle, $R_{\mathrm{Ct}}$ is the fluorescence at this cycle, $\mathrm{E}$ is amplification efficiency (calculated from a standard curve) and $R_{0}$ is starting fluorescence, which is proportional to the starting template quantity. Starting template copy numbers estimated using the linear regression efficiency method described by Rutledge et al [31] were in broad agreement with the above method (Additional file 2: Figure S1) and mean values from the two methods were calculated.

\section{In situ hybridization (ISH)}

Mice were euthanised as described above. Eyes were enucleated, fixed in $4 \%$ PFA for $1 \mathrm{~h}$ at $4{ }^{\circ} \mathrm{C}$ and cryoprotected trough series of 10,20 and $30 \%$ sucrose, for $1-3 \mathrm{~h}$, embedded in optimal cutting temperature compound (OCT, Sakura, Japan) and snap frozen in an isopentane bath on dry ice. CE-RSC spheres were collected and fixed in $4 \%$ PFA for $30 \mathrm{~min}$ at $4{ }^{\circ} \mathrm{C}$, cryoprotected in $30 \%$ sucrose over night, embedded in OCT and snap frozen on dry ice. Locked nucleic acid probes (miRCURY ${ }^{\mathrm{mm}}$ LNA Detection, Exiqon) for the candidate miRNAs and a scrambled miRNA control probe (Table 5), were prelabelled with digoxygenin (DIG) at the $5^{\prime}$ end. $10 \mu \mathrm{m}$ cryosections were fixed in 4\% PFA for 10 minutes, rinsed in $1 \times$ PBS and $100 \mu \mathrm{l}$ of hybridisation mix (50\% formamide, $0.3 \mathrm{M} \mathrm{NaCl}, 20 \mathrm{mM}$ Tris- $\mathrm{HCl} \mathrm{pH} 8,10 \%$ dextran sulphate, $1 \times$ Denhardt's solution, $1 \mathrm{mg} / \mathrm{ml}$ yeast rRNA) containing $2 \mu \mathrm{l}$ of probe/ml was applied to sections. Slides were covered with glass cover slips and hybridisation was performed overnight at $20^{\circ} \mathrm{C}$ below the $\mathrm{Tm}$. 
Slides were washed twice in $1 \times$ SSC, $50 \%$ formamide, $0.1 \%$ Tween 20 for $30 \mathrm{~min}$, and once in $1 \times$ SSC, $0.1 \%$ Tween 20 and $0.2 \times$ SSC $0.1 \%$ Tween 20 for 30 minutes at $65^{\circ} \mathrm{C}$. Two washes in $1 \times$ MABT $(100 \mathrm{mM}$ maleic acid, $150 \mathrm{mM} \mathrm{NaCl}, 0.1 \%$ Tween 20, $\mathrm{pH}$ 7.5) were performed at RT for 30 minutes. After incubation in blocking solution containing $1 \times$ MABT, 2\% blocking reagent (Roche, Mannheim, Germany) and 20\% heat inactivated sheep serum (Sigma-Aldrich, Poole, UK) for 2 hours at RT, anti-digoxygenin Fab fragments (Roche, Mannheim, Germany) were applied at 1:5,000 dilution overnight at RT. Detection staining was performed by incubation with the alkaline phosphatase chromogenic substrate 5-bromo-4chloro-3-indolylphosphate/nitro-blue tetrazolium (BCIP/ NBT) (Roche, Mannheim, Germany).

Additional file 1: Table S1. Significance of predicted effects of miRNAs upon mRNA expression in all gene expression datasets (CE-RSCS, P4 and adult retina) and p-values calculated using Fisher's combined probability test.

Click here for file

[http://www.biomedcentral.com/content/supplementary/1471-213X-10-1S1.XLS ]

Additional file 2: Figure S1. miRNA expression detected by RT-PCR. (A) Comparison of relative miRNA expression calculated using a standard curve (as shown in Figure $3 \mathrm{~A}$ ) with the values calculated using $\Delta \mathrm{Ct}$ and efficiency; for each gene the sample with highest expression was normalized to a value of 100. Each point represents the expression of one miRNA in a single sample as determined by both methods, which yielded very similar results $\left(R^{2}=0.983\right)$. (B) Starting template copy numbers estimated for each miRNA based on threshold cycle $(C t)$ and amplification efficiency plotted against the values calculated by a linear regression efficiency method [31] $\left(\mathrm{R}^{2}=0.661\right)$.

Click here for file

[http://www.biomedcentral.com/content/supplementary/1471-213X-10-1S2.PDF ]

Additional file 3: Table S2. All genes predicted to be targeted by candidate miRNAs affecting mRNA levels in each tissue. Genes assessed experimentally for miRNA interactions are highlighted in bold. Click here for file

[http://www.biomedcentral.com/content/supplementary/1471-213X-10-1S3.XLS ]

Additional file 4: Table S3. The categories of functional annotations enriched within those genes predicted to be targeted by two or more candidate miRNAs affecting mRNA levels within CE-RSCs, PE or adult retina. Analyses were performed using the DAVID bioinformatics database [35]; categories with $p<0.05$ after correction for multiple comparisons (Benjamini) are listed.

Click here for file

[ http://www.biomedcentral.com/content/supplementary/1471-213X-10-1S4.XLS ]

\section{Acknowledgements}

The authors would like to acknowledge the contribution of all the researchers who have made their gene expression data publicly available and without whom this study would not have been possible.

\section{Authors' contributions}

AA performed bioinformatic analyses and some laboratory work; JG-F performed RT-PCR and ISH and contributed to manuscript preparation. LH performed miRNA transfections and mRNA RT-PCR. MD performed microarray analysis with P4 mice; TC contributed to supervision and manuscript preparation; DAS conceived and supervised the study, performed bioinformatic analyses and prepared the manuscript. All authors read and approved the final manuscript.

Received: 18 March 2009

Accepted: 6 January 2010 Published: 6 January 2010

\section{References}

1. Bartel DP: MicroRNAs: genomics, biogenesis, mechanism, and function. Cell 2004, 116(2):281-297.

2. Lee RC, Feinbaum RL, Ambros V: The C. elegans heterochronic gene lin-4 encodes small RNAs with antisense complementarity to lin-14. Cell 1993, 75(5):843-854

3. Reinhart BJ, Slack FJ, Basson M, Pasquinelli $A E$, Bettinger JC, Rougvie $A E$, Horvitz HR, Ruvkun G: The 21-nucleotide let-7 RNA regulates developmental timing in Caenorhabditis elegans. Nature 2000, 403(6772):901-906

4. Wightman B, Ha I, Ruvkun G: Posttranscriptional regulation of the heterochronic gene lin-14 by lin- 4 mediates temporal pattern formation in C. elegans. Cell 1993, 75(5):855-862.

5. Stefani G, Slack FJ: Small non-coding RNAs in animal development. Nat Rev Mol Cell Biol 2008, 9(3):219-230.

6. Damiani D, Alexander JJ, O'Rourke JR, McManus M, Jadhav AP, Cepko CL, Hauswirth WW, Harfe BD, Strettoi E: Dicer inactivation leads to progressive functional and structural degeneration of the mouse retina. J Neurosci 2008, 28(19):4878-4887.

7. Li X, Carthew RW: A microRNA mediates EGF receptor signaling and promotes photoreceptor differentiation in the Drosophila eye. Cell 2005, 123(7):1267-1277.

8. Ryan DG, Oliveira-Fernandes M, Lavker RM: MicroRNAs of the mammalian eye display distinct and overlapping tissue specificity. Mol Vis 2006, 12:1175-1184.

9. Karali M, Peluso I, Marigo V, Banfi S: Identification and characterization of microRNAs expressed in the mouse eye. Invest Ophthalmol Vis Sci 2007, 48(2):509-515.

10. Makarev E, Spence JR, Del Rio-Tsonis K, Tsonis PA: Identification of microRNAs and other small RNAs from the adult newt eye. Mol Vis 2006, 12:1386-1391.

11. Xu S, Witmer PD, Lumayag S, Kovacs B, Valle D: MicroRNA (miRNA) Transcriptome of Mouse Retina and Identification of a Sensory Organspecific miRNA Cluster. J Biol Chem 2007, 282(34):25053-25066.

12. Loscher CJ, Hokamp K, Wilson JH, Li T, Humphries P, Farrar GJ, Palfi A: A common microRNA signature in mouse models of retinal degeneration. Exp Eye Res 2008, 87(6):529-534.

13. Loscher CJ, Hokamp K, Kenna PF, Ivens AC, Humphries P, Palfi A, Farrar GJ: Altered retinal microRNA expression profile in a mouse model of retinitis pigmentosa. Genome Biol 2007, 8(11):R248.

14. Arora A, McKay GJ, Simpson DA: Prediction and Verification of miRNA Expression in Human and Rat Retinas. Invest Ophthalmol Vis Sci 2007, 48(9):3962-3967.

15. Pillai RS, Bhattacharyya SN, Filipowicz W: Repression of protein synthesis by miRNAs: how many mechanisms?. Trends Cell Biol 2007, 17(3):118-26.

16. Baek D, Villen J, Shin C, Camargo FD, Gygi SP, Bartel DP: The impact of microRNAs on protein output. Nature 2008, 455(7209):64-71.

17. Selbach M, Schwanhausser B, Thierfelder N, Fang Z, Khanin R, Rajewsky N: Widespread changes in protein synthesis induced by microRNAs. Nature 2008, 455(7209):58-63.

18. Lim LP, Lau NC, Garrett-Engele P, Grimson A, Schelter JM, Castle J, Bartel DP, Linsley PS, Johnson JM: Microarray analysis shows that some microRNAs downregulate large numbers of target mRNAs. Nature 2005, 433(7027):769-773.

19. Lagos-Quintana M, Rauhut R, Yalcin A, Meyer J, Lendeckel W, Tuschl T: Identification of tissue-specific microRNAs from mouse. Curr Biol 2002, 12(9):735-739.

20. Sood P, Krek A, Zavolan M, Macino G, Rajewsky N: Cell-type-specific signatures of microRNAs on target mRNA expression. Proc Natl Acad SCi USA 2006, 103(8):2746-2751.

21. Yu Z, Raabe T, Hecht NB: MicroRNA Mirn122a reduces expression of the posttranscriptionally regulated germ cell transition protein 2(Tnp2) messenger RNA (mRNA) by mRNA cleavage. Biol Reprod 2005, 73(3):427433. 
22. Krutzfeldt J, Rajewsky N, Braich R, Rajeev KG, Tuschl T, Manoharan M, Stoffel M: Silencing of microRNAs in vivo with 'antagomirs'. Nature 2005, 438(7068):685-689.

23. Grimson A, Farh KK, Johnston WK, Garrett-Engele P, Lim LP, Bartel DP: MicroRNA targeting specificity in mammals: determinants beyond seed pairing. Mol Cell 2007, 27(1):91-105

24. Lewis BP, Burge CB, Bartel DP: Conserved seed pairing, often flanked by adenosines, indicates that thousands of human genes are microRNA targets. Cell 2005, 120(1):15-20.

25. Maziere P, Enright AJ: Prediction of microRNA targets. Drug Discov Today 2007, 12(11-12):452-458.

26. Krek A, Grun D, Poy MN, Wolf R, Rosenberg L, Epstein EJ, MacMenamin P, da Piedade I, Gunsalus KC, Stoffel M, Rajewsky N: Combinatorial microRNA target predictions. Nat Genet 2005, 37(5):495-500.

27. Griffiths-Jones S, Saini HK, van Dongen S, Enright AJ: miRBase: tools for microRNA genomics. Nucleic Acids Res 2008, 36 Database: D154-8.

28. miRBase. http://microrna.sanger.ac.uk/

29. Arora A, Simpson DA: Individual mRNA expression profiles reveal the effects of specific microRNAs. Genome Biol 2008, 9(5):R82.

30. Elmen J, Lindow M, Silahtaroglu A, Bak M, Christensen M, Lind-Thomsen A, Hedtjarn M, Hansen JB, Hansen HF, Straarup EM, McCullagh K, Kearney P, Kauppinen S: Antagonism of microRNA-122 in mice by systemically administered LNA-antimiR leads to up-regulation of a large set of predicted target mRNAs in the liver. Nucleic Acids Res 2008, 36(4):1153-62.

31. Rutledge RG, Stewart D: A kinetic-based sigmoidal model for the polymerase chain reaction and its application to high-capacity absolute quantitative real-time PCR. BMC Biotechnol 2008, 8:47.

32. Zhang K, Kniazeva M, Han M, Li W, Yu Z, Yang Z, Li Y, Metzker ML, Allikmets R, Zack DJ, Kakuk LE, Lagali PS, Wong PW, MacDonald IM, Sieving PA, Figueroa DJ, Austin CP, Gould RJ, Ayyagari R, Petrukhin K: A 5bp deletion in ELOVL4 is associated with two related forms of autosomal dominant macular dystrophy. Nat Genet 2001, 27(1):89-93.

33. Lagali PS, Liu J, Ambasudhan R, Kakuk LE, Bernstein SL, Seigel GM Wong PW, Ayyagari R: Evolutionarily conserved ELOVL4 gene expression in the vertebrate retina. Invest Ophthalmol Vis Sci 2003, 44(7):2841-2850.

34. Krishnan A, Venkataraman V, Fik-Rymarkiewicz E, Duda T, Sharma RK Structural, biochemical, and functional characterization of the calcium sensor neurocalcin delta in the inner retinal neurons and its linkage with the rod outer segment membrane guanylate cyclase transduction system. Biochemistry 2004, 43(10):2708-2723.

35. Huang da W, Sherman BT, Lempicki RA: Systematic and integrative analysis of large gene lists using DAVID bioinformatics resources. Nat Protoc 2009, 4(1):44-57.

36. Das AV, James J, Rahnenfuhrer J, Thoreson WB, Bhattacharya S, Zhao X, Ahmad I: Retinal properties and potential of the adult mammalian ciliary epithelium stem cells. Vision Res 2005, 45(13):1653-1666.

37. Wienholds E, Plasterk RH: MicroRNA function in animal development. FEBS Lett 2005, 579(26):5911-5922.

38. Gu P, Harwood LJ, Zhang X, Wylie M, Curry WJ, Cogliati T: Isolation of retinal progenitor and stem cells from the porcine eye. Mol Vis 2007, 13:1045-1057

39. Coles BL, Angenieux B, Inoue T, Del Rio-Tsonis K, Spence JR, Mclnnes RR Arsenijevic $Y$, Kooy van der D: Facile isolation and the characterization of human retinal stem cells. Proc Natl Acad Sci USA 2004, 101(44):1577215777.

40. Inoue $Y$, Yanagi $Y$, Tamaki $Y$, Uchida S, Kawase $Y$, Araie M, Okochi H: Clonogenic analysis of ciliary epithelial derived retinal progenitor cells in rabbits. Exp Eye Res 2005, 81(4):437-445.

41. Xu S, Sunderland ME, Coles BL, Kam A, Holowacz T, Ashery-Padan R, Marquardt T, Mclnnes RR, Kooy van der D: The proliferation and expansion of retinal stem cells require functional Pax6. Dev Biol 2007, 304(2):713-721.

42. Walker JC, Harland RM: microRNA-24a is required to repress apoptosis in the developing neural retina. Genes Dev 2009, 23(9):1046-1051.

43. Wang $Q$, Huang $Z$, Xue $H$, Jin C, Ju XL, Han JD, Chen YG: MicroRNA miR-24 inhibits erythropoiesis by targeting activin type I receptor ALK4. Blood 2008, 111(2):588-595

44. Tzur G, Levy A, Meiri E, Barad O, Spector Y, Bentwich Z, Mizrahi L, Katzenellenbogen M, Ben-Shushan E, Reubinoff BE, Galun E: MicroRNA expression patterns and function in endodermal differentiation of human embryonic stem cells. PLOS ONE 2008, 3(11):e3726.
45. Kapsimali M, Kloosterman WP, de Bruijn E, Rosa F, Plasterk RH, Wilson SW: MicroRNAs show a wide diversity of expression profiles in the developing and mature central nervous system. Genome Biol 2007, 8(8): R173.

46. Smirnova L, Grafe A, Seiler A, Schumacher S, Nitsch R, Wulczyn FG: Regulation of miRNA expression during neural cell specification. Eur $J$ Neurosci 2005, 21(6):1469-1477.

47. Makeyev EV, Zhang J, Carrasco MA, Maniatis T: The MicroRNA miR-124 promotes neuronal differentiation by triggering brain-specific alternative pre-mRNA splicing. Mol Cell 2007, 27(3):435-448.

48. Bak M, Silahtaroglu A, Moller M, Christensen M, Rath MF, Skryabin B, Tommerup N, Kauppinen S: MicroRNA expression in the adult mouse central nervous system. RNA 2008, 14(3):432-44.

49. Visvanathan J, Lee S, Lee B, Lee JW, Lee SK: The microRNA miR-124 antagonizes the anti-neural REST/SCP1 pathway during embryonic CNS development. Genes Dev 2007, 21(7):744-749.

50. Leucht C, Stigloher C, Wizenmann A, Klafke R, Folchert A, Bally-Cuif L: MicroRNA-9 directs late organizer activity of the midbrain-hindbrain boundary. Nat Neurosci 2008, 11(6):641-648.

51. Krichevsky AM, Sonntag KC, Isacson O, Kosik KS: Specific microRNAs modulate embryonic stem cell-derived neurogenesis. Stem Cells 2006, 24(4):857-864.

52. Wu L, Fan J, Belasco JG: MicroRNAs direct rapid deadenylation of mRNA Proc Natl Acad Sci USA 2006, 103(11):4034-4039.

53. Wu L, Belasco JG: Let me count the ways: mechanisms of gene regulation by miRNAs and siRNAs. Mol Cell 2008, 29(1):1-7.

54. Barrett $T$, Troup DB, Wilhite SE, Ledoux P, Rudnev D, Evangelista C, Kim IF, Soboleva A, Tomashevsky M, Edgar R: NCBI GEO: mining tens of millions of expression profiles-database and tools update. Nucleic Acids Res 2007, 35 Database: D760-5.

55. Gene Expression Omnibus (GEO). http://www.ncbi.nlm.nih.gov/projects/ geo/.

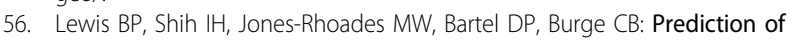
mammalian microRNA targets. Cell 2003, 115(7):787-798.

57. TargetScan: Prediction of microRNA targets. http://www.targetscan.org/.

58. The Comprehensive R Archive Network. http://cran.r-project.org/.

59. BioMart Project. http://www.biomart.org/.

60. Fisher RA: Statistical Methods for Research Workers Edinburgh: Oliver and Boyd 1932.

61. Shi R, Chiang VL: Facile means for quantifying microRNA expression by real-time PCR. BioTechniques 2005, 39(4):519-525.

62. miRBase: the microRNA database. http://www.mirbase.org/.

63. Griffiths-Jones S, Grocock RJ, van Dongen S, Bateman A, Enright AJ: miRBase: microRNA sequences, targets and gene nomenclature. Nucleic Acids Res 2006, 34 Database: D140-4

64. Paper W, Kroeber M, Heersink S, Stephan DA, Fuchshofer R, Russell P, Tamm ER: Elevated amounts of myocilin in the aqueous humor of transgenic mice cause significant changes in ocular gene expression. Exp Eye Res 2008, 87(3):257-267.

65. Steele MR, Inman DM, Calkins DJ, Horner PJ, Vetter ML: Microarray analysis of retinal gene expression in the DBA/2J model of glaucoma. Invest Ophthalmol Vis Sci 2006, 47(3):977-985.

66. Akimoto M, Cheng H, Zhu D, Brzezinski JA, Khanna R, Filippova E, Oh EC, Jing $Y$, Linares $J$, Brooks M, Zareparsi S, Mears AJ, Hero A, Glaser T, Swaroop A: Targeting of GFP to newborn rods by Nrl promoter and temporal expression profiling of flow-sorted photoreceptors. Proc Natl Acad Sci USA 2006, 103(10):3890-3895.

\section{doi:10.1186/1471-213X-10-1}

Cite this article as: Arora et al:: Prediction of microRNAs affecting mRNA expression during retinal development. BMC Developmental Biology 2010 10:1. 